\title{
Identification of Quantitative Trait Loci Determining Vegetative Growth Traits in Coffea canephora
}

\author{
Identifikasi Kuantitatif Trait Loci Penentu Karakter \\ Pertumbuhan Vegetative Coffea canephora
}

\author{
Priyono $^{\left.1^{*}\right)}$, Ucu Sumirat ${ }^{1)}$ and Dominique Crouzillat ${ }^{2)}$
}

\begin{abstract}
Summary
Recently the use of molecular markers has been successfully applied for some crops. For coffee, new opportunities have been opened since Nestlé R\&D Centre in collaboration with ICCRI completed the first genetic map of Coffea canephora. This study was aimed both to evaluate the phenotypic trait and also to identify the quantitative trait loci (QTLs) controlling the vegetative growth in Robusta coffee. Present study used three $C$. canephora populations and six genetic maps developed based on these populations using simple sequence repeats (SSRs) and single nucleotide polymorphisms (SNPs) markers. A total of 17 different quantitative data were used for the detection of QTLs on each of three populations. Present result showed that most of these traits were not heritable. The nine vegetative traits have been identified and distributed over seven different linkage groups. Due to some QTLs determining one given trait were overlapping on the same linkage group and were coming from the same favourable parent, a total of 19 QTLs detected for vegetative traits might finally be considered as only 12 QTLs involved. However, only two of them were shared for different traits. One involved for the number/length of primary branches and width of the canopy while the other for length of internodes and width of canopy. These two QTLs might determine the size of the tree canopy in this species.
\end{abstract}

Key words: Coffea canephora, heridity, quantitative trait loci (QTLs), vegetative growth.

\section{Ringkasan}

Saat ini penggunaan marka molekuler telah berhasil diterapkan pada berbagai tanaman. Peluang penggunaan marka tersebut pada kopi Robusta (Coffea canephora) terbuka setelah berhasil dikonstruksi peta genetik sebagai hasil kerjasama antara Pusat Penelitian Kopi dan Kakao Indonesia dengan Nestlé R\&D Centre Perancis. Penelitian ditujukan untuk mengevaluasi data fenotipik maupun mengidentifikasi quantitative trait loci (QTLS) yang terkait dengan pertumbuhan vegetatif kopi. Penelitian menggunakan tiga populasi dan enam peta genetik yang dikembangkan dari ketiga populasi tersebut. Hasil penelitian menunjukkan bahwa nilai heriditas sangat kecil ditemui pada sebagian besar data, sehingga jika hanya berdasarkan pengamatan fenotipik, maka pemanfaatan tetua tersebut untuk memperbaiki genetik pada keturunan kurang baik. Hasil analisis QTLs menunjukkan bahwa 19 QTL terkait dengan sembilan karakter pertumbuhan vegetatif dan dapat diidentifikasi tersebar pada tujuh kromosom. Namun demikian, sehubungan ditengarai adanya

Naskah diterima (received) 28 Februari 2011, disetujui (accepted) 12 April 2011.

1) Pusat Penelitian Kopi dan Kakao Indonesia, Jl. PB. Sudirman No. 90, Jember, Indonesia.

2) Nestle R\&D Centre, 101 Avenue Gustave Eiffel, 37097 Tours Cedex 2, France

*) Alamat penulis (Corresponding Author) : priyono_iccri@yahoo.com 
QTL yang sama, maka akhirnya ditetapkan bahwa sebanyak 12 QTL yang terkait dengan sifat pertumbuhan vegetatif tersebut. Terdapat dua QTL yang sangat terkait dengan dua QTL lainnya, yaitu QTL jumlah/panjang cabang primer dan QTL lebar kanopi, serta QTL panjang buku dengan QTL lebar kanopi. Hasil ini menunjukkan bahwa kedua QTL ini sangat menentukan ukuran kanopi kopi.

\section{INTRODUCTION}

The introduction of Robusta coffee (Coffea canephora Pierre) to Indonesia in 1900 (Cramer, 1957) was one of the most important efforts to meet coffee production sustainability after Arabica coffee (Coffea arabica L.) devastation by leaf rust (Hemileia vastratrix B. \& Br.). Today, Robusta coffee dominates coffee growing in Indonesia, and the Arabica is only cultivated in high altitude areas.

Up to now, Robusta coffee breeding is generaly based on phenotypical characteristics. The breeding process includes selection of superior progenies derived from controlled pollination. Diallelic crosses are commonly used to evaluate the general and specific combining abilities for estimating genetic potential for each observed trait. This process has been called "conventional breeding". Unfortunately, up to now, a conventional method lacks genetic markers to be used for screening and breeding guidance (Leroy, 1994; Eskes \& Leroy, 2004).

One of the main constraints in conventional coffee breeding is the difficulty to estimate the genetic $\mathrm{x}$ environment interactions (Allard \& Bradshaw, 1964). This problem is even more complicated on polygenics quantitative characteristics. As a perennial crop, coffee takes several years to be properly evaluated. The combination of the two above constraints is making coffee breeding highly time consuming.

A coffee linkage map and a quantitative trait loci (QTL) analysis for valuable traits will help coffee breeders to select superior plants by identifying the DNA markers linked to the loci determining these desirable traits (Poncet et al., 2007; Hendre \& Aggarwal, 2007; Lefebvre-Pautigny et al., 2010). When the QTLs have been identified and characterized, the breeding program will be adapted accordingly. In assessing coffee seedlings, breeders will only need to collect young coffee leaves. At the laboratory, DNA will be extracted and the use of molecular markers will allow the identification of the seedlings having expected traits for field observation. It will significantly improve efficiency through saving land and labour. Breeders will not wait many years in assessing the whole breeding populations since they could discard most of the individuals not having desirable traits. However, breeders will still have to verify in fields the value of selected trees before releasing elite clones. This early screening is called "molecular breeding". Its efficiency would be improved and new clones pyramiding the QTLs of interest could be selected. Present paper presented our study in QTLs identification determining the vegetative growth of Robusta coffee. 


\section{MATERIALS AND METHODS}

\section{Planting Materials}

This study involves three parental clones (BP 409, BP 961, and Q 121) of C. canephora and three controlled hybrid populations i.e., $\mathrm{CPA}=\mathrm{BP} 961 \times \mathrm{Q} 121$, $\mathrm{CPB}=\mathrm{BP} 409 \times \mathrm{Q} 121$, and $\mathrm{CPC}=\mathrm{BP} 409$ $x$ BP 961. The choice of these parents was based on the results of genetic diversity and heterozigosity studies previously reported by Priyono (1998). Moreover, by using genetic diversity of 143 acessions of $C$. canephora indicated that these three parents belong to two different groups, namely Q 121 to Guinean x Conillon hybrid group, and BP 409 and BP 961 to Congolese group (Priyono et al., 2010a). The controlled pollination was carried out manually during the dry period after watering to stimulate flowering as described by Iswanto et al. (1984). We finally obtained 78, 93, and 82 hybrid plants respectively for $\mathrm{CPA}, \mathrm{CPB}$, and $\mathrm{CPC}$. The hybrid plants were transplanted in two different locations based on elevation and climate type according to Schmidt and Ferguson (1951). These are Lampung (850 $\mathrm{m} \mathrm{dpl,} \mathrm{climate} \mathrm{type} \mathrm{A)} \mathrm{and} \mathrm{Jember}$ (45 m dpl, climate type D). The Lampung one is representing wet-climate, while the Jember one is representing dry-climate.

Coffee trees were conducted in single stem system. Each tree was topped at two stages, namely the first at $120-140 \mathrm{~cm}$ and the second at $160-180 \mathrm{~cm}$. On each stage two or three plagiotrophic branches were capped for initiating a frame of productive branches. In order to facilitate light distribution in the canopy, the plagiotrophic branches of each pruning stage were managed in opposite direction. Regular pruning is applied to maintain the growth of productive branches. These three popu- lations were used to create genetic maps and quantitative data were used to identify molecular markers linked to vegetative growth traits.

\section{Genotype Data Collection}

Observations of pre-yielding plants were carried out one year after field transplantation. The observations consisted of 1) Plant height, 2) Trunk diameter, 3) Canopy width, 4) Number of primary branches, 5) Number of primary branch pairs, 6) Total number of nodes per branch, 7) Number of nodes per primary branch. The observations were done in both locations Jember and Lampung.

The observed vegetative characteristics were stipulate length, petiole length, leaf length and leaf width. Each characteristic was observed on five randomly selected nodes. The measurement of stipulate and petiole lengths were carried out from basal to distal end on flowers at candle stage on the second young node. Length and width of leaves were measured from basal to distal end, in the longest and widest part of leaf. The observations of these traits were done for 4 years old trees from only one location in Jember.

The canopy width was measured in two directions at widest part of the canopy. The canopy width and internodes length were observed for 4, 6, 7 and 8 years old in both locations: Jember and Lampung.

\section{Quantitative Data Analysis}

Correlation tests between data of observed traits were performed by the Pearson test with NCSS software with $\alpha=0.01$. Distribution tests for data of observed traits were carried out using Kolmogorov-Smirrow test with Statbox6 software with $\alpha=0.05$. Both one way 
and repeated measures Anova followed by Tukey-Kramer comparison test, were performed with NCSS software with $\alpha=0.05$. Heritability is the relative amount of variation caused by genetics. Heritability ranges from 0 to 1 . High heritability means that most of the variation among individuals is caused by genetics and not by the environment. ANOVA analysis performed by Statbox6 software estimated the heritability for each trait.Estimated narrow heritability is defined as Priyono et al. (2010b). Six genetic maps based on SSR and SNPs markers: i.e three cross pollinated (CP) genetic maps and three backcross (BC) genetic maps, and one consensus map was created from the three $\mathrm{CP}$ genetic maps (Priyono et al., 2010a) was used to localize the detected QTL on linkage group regions.

The MapQTL5 ${ }^{\circledast}$ software (van Ooijen, 2004) was used for QTLs analysis. The genetic linkage groups carrying QTLs were represented using MapChart software (van Ooijen, 2006). MAPQTL used for QTL interval mapping in CP populations assumes four QTL genotypes (ac, ad, bc, bd) and fits four averages by weighted regression process. This process is iterative following the hereafter steps for each location:

a. To estimate the QTL genotypes probabilities from flanking marker information.

b. To perform a regression analysis, using the QTL genotypes as weight for estimating the trait means for each QTL genotype and the residual variance.

c. To update the QTL genotype probabilities using flanking marker information and QTL mean estimates.

d. Repeat step b and c until the likelihood converges.
To have a high confidence of the QTLs analysis result, we used the following strategies:

a. Firstly, testing of variance by KruskalWallis (KW) non-parametric. This compares the medians of each genotype class and return to the statistic $\mathrm{K}$, which has an approximate chi-squared distribution with degrees of freedom $=$ number of classes -1 . We look for the most significant marker. Unless all markers have the same number of classes, it is probably better to carry out the permutation test for the significance, and then convert this back to the corresponding $\mathrm{K}$ value. So far with a $5 \%$ permutation test we would look for a $\mathrm{K}$ value of at least 12.86 for 2 genotype classes and 18.6 for four classes.

b. Secondly, calculating Interval Mapping (IM). Genome wide LOD thresholds of a given trait were experimentally determined by using the Permutation test of MAPQTL with 1,000 interactions. Based on the permutation test, a threshold LOD value of 4 for $\mathrm{CP}$ and 3 for $\mathrm{BC}$ maps were used to declare the presence of a QTL.

c. Thirdly, combining the results from Kruskal-Wallis and Interval Mapping (C Hackett, personal communication).

- Both significant

When both, KW and IM, show a QTL in a given location, one can be confident of having identified a real QTL.

- KW significant but not IM

This is most likely due to an outlier affecting the mean but not the median. In general, if the KW test is highly significant there is probably a QTL present but one has to be careful of borderline significant effects. 
- IM significant but not KW

Check for large numbers of iterations and/or a QTL location far away from the markers. Another explanation might be a region where there is little marker information from one of the parents. If none of these apply, we would then check for outlier.

d. Fourthly, mapping for each parent separately. If $\mathrm{KW}$ suggests that the QTL is behaving as a backcross, and interval mapping is overfitting four means, then the marker information for the parent of interest can be recoded as a backcross and used for QTL mapping to force the fitting of two QTL means only.

\section{RESULTS AND DISCUSSION}

The observation of vegetative growth traits involved nine characteristics, which were differentiated in two sub-groups according to the development stage: preyielding plants ( 1 year-old plant) and yielding plants (4, 6, 7 and 8 years old plants).

For coffee, one of the main goals for genetic improvement is to increase the productivity (Bouharmont et al., 1986). It would therefore be a matter of determining which shapes lead to an optimized cherries yield, is stable over time, with as little as possible competition with vegetative growth (Cilas et al., 2006). It is a quite complex trait influenced by many characteristics. For this reason, we have observed a large number of diverse vegetative traits over a long period of time (from year one to year eight) after transplantation in different fields and sites. The data recorded for the observed vegetative growth traits are summarized in Table 1.

Significant correlations $(\alpha<0.1 \%)$ between some vegetative traits have been detected. The correlation value among vegetative growth traits are summarized in Table 2 to 4 . Number of node at $3^{\text {rd }}$ primary branch was positively correlated with length of the same branch and negatively correlated with length of internodes of the same branch. The length of stipule of yielding plant at Jember was positively correlated with length of internodes of 4 year-old plant. Group of positive correlation concerned the wide canopy of 6 year-old plant (Jember) to wide canopy of 8 year-old plant (Lampung), average of wide canopy for over years observation (Lampung) and average of length of internodes for over years observation (Lampung) were observed. Wide canopy of 8 year-old plant (Lampung) was positively correlated with average of length of internodes over year (Lampung). Another group of positive correlation was recorded for length of internodes both for 4 and 7 year-old plant (Jember) with length of internodes for 7 year-old plant (Jember) and average of length of internodes over years (Jember). Present result showed that some of these correlations are quite obvious because they are established between related characters. For example, the number of nodes of a given branch is positively correlated to the length of this branch. Other correlations are more interesting. For example, the width of the canopy in Jember (6 year-old plant) is correlated to the width of the canopy in Lampung (8 year-old plant). This correlation indicates a genetic effect more important than the environment effect for this trait.

Currently clones used as parents in conventional plant breeding are selected for significant differences between interesting traits. In this study, the parental clones were firstly selected for their ge- 
Identification of quantitative trait loci determining vegetative growth traits in Robusta coffee

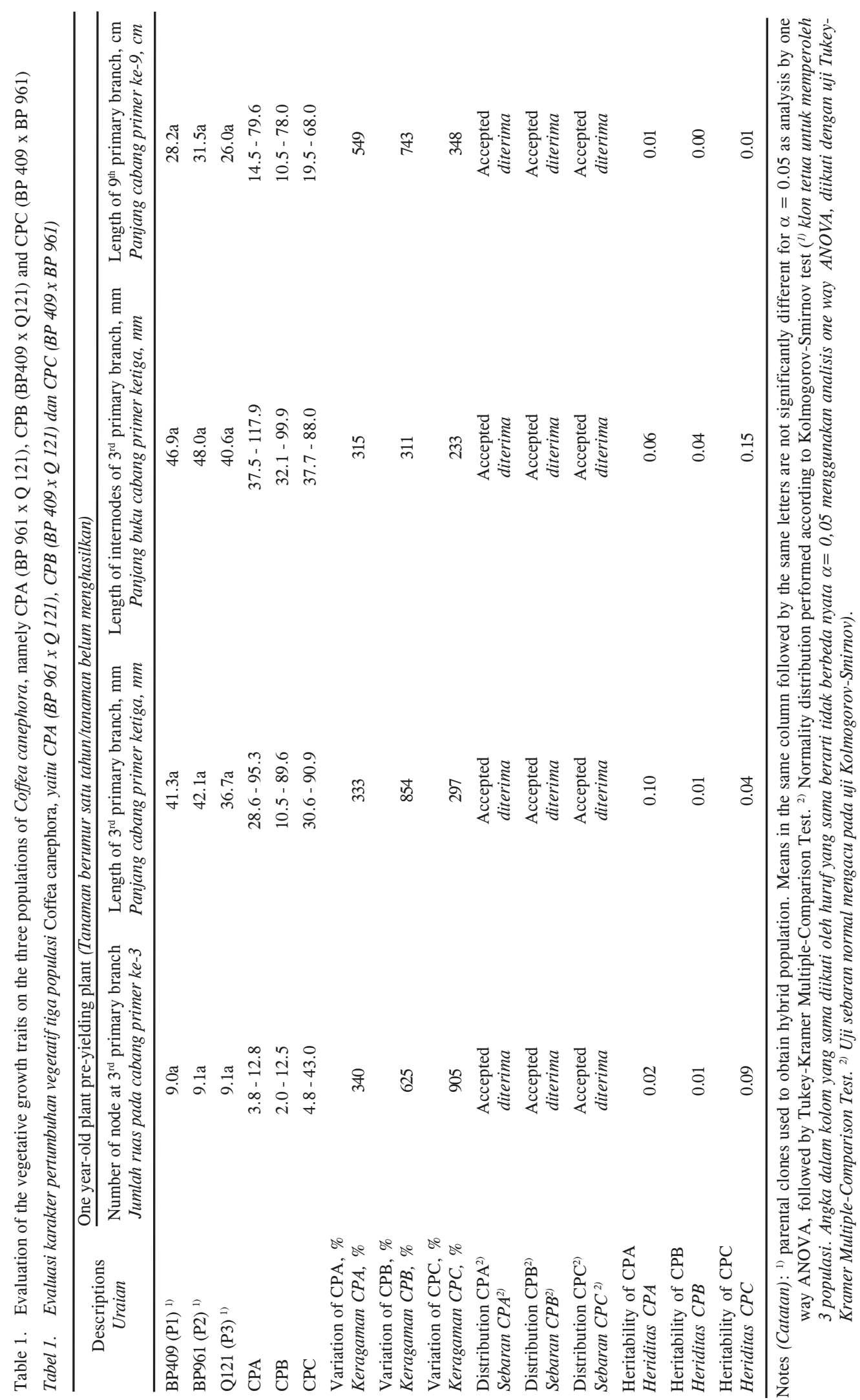

PELITA PERKEBUNAN, Volume 27, Nomor 3, Edisi Desember 2011 


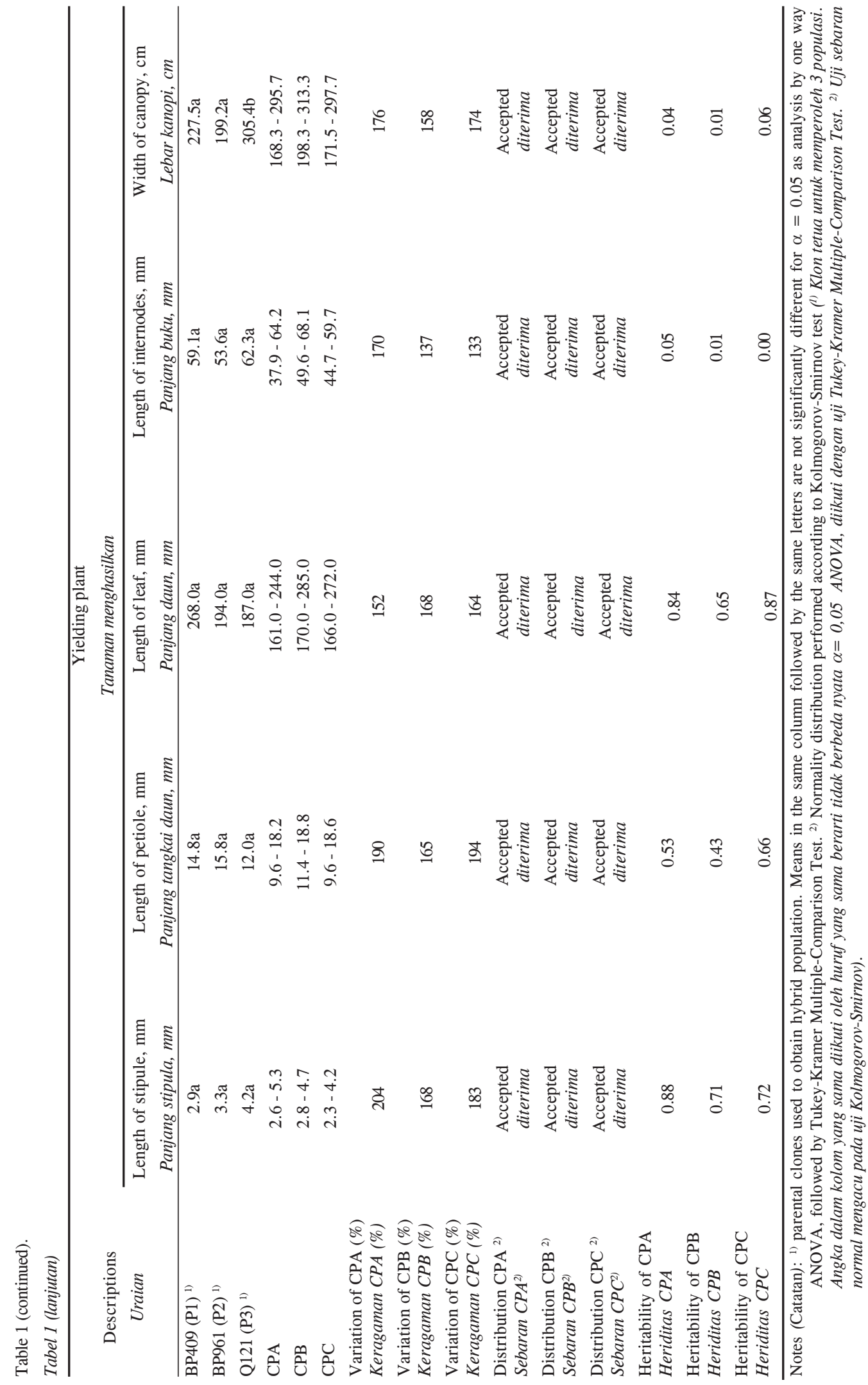

PELITA PERKEBUNAN, Volume 27, Nomor 3, Edisi Desember 2011 
Identification of quantitative trait loci determining vegetative growth traits in Robusta coffee

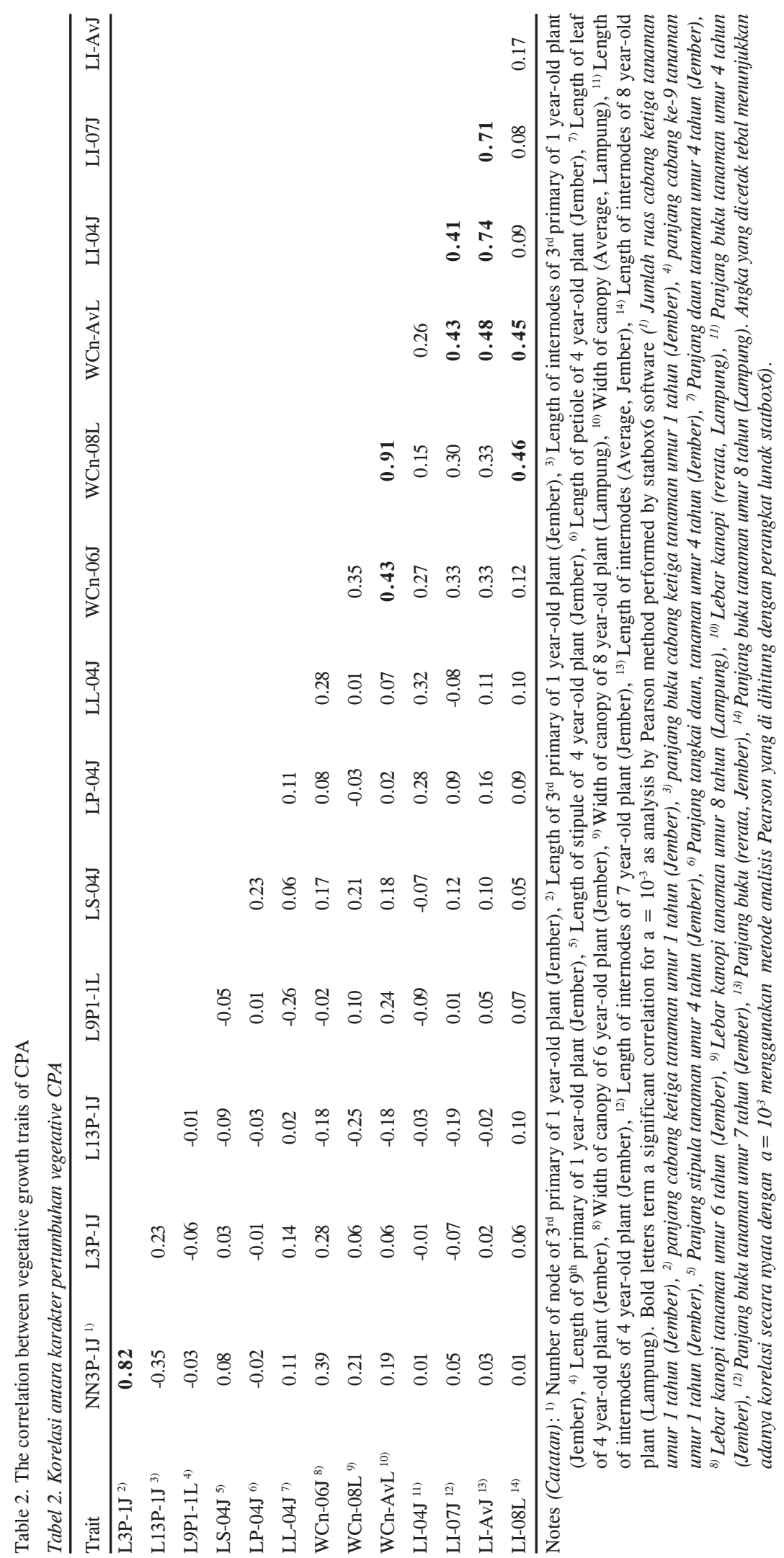

PELITA PERKEBUNAN, Volume 27, Nomor 3, Edisi Desember 2011 

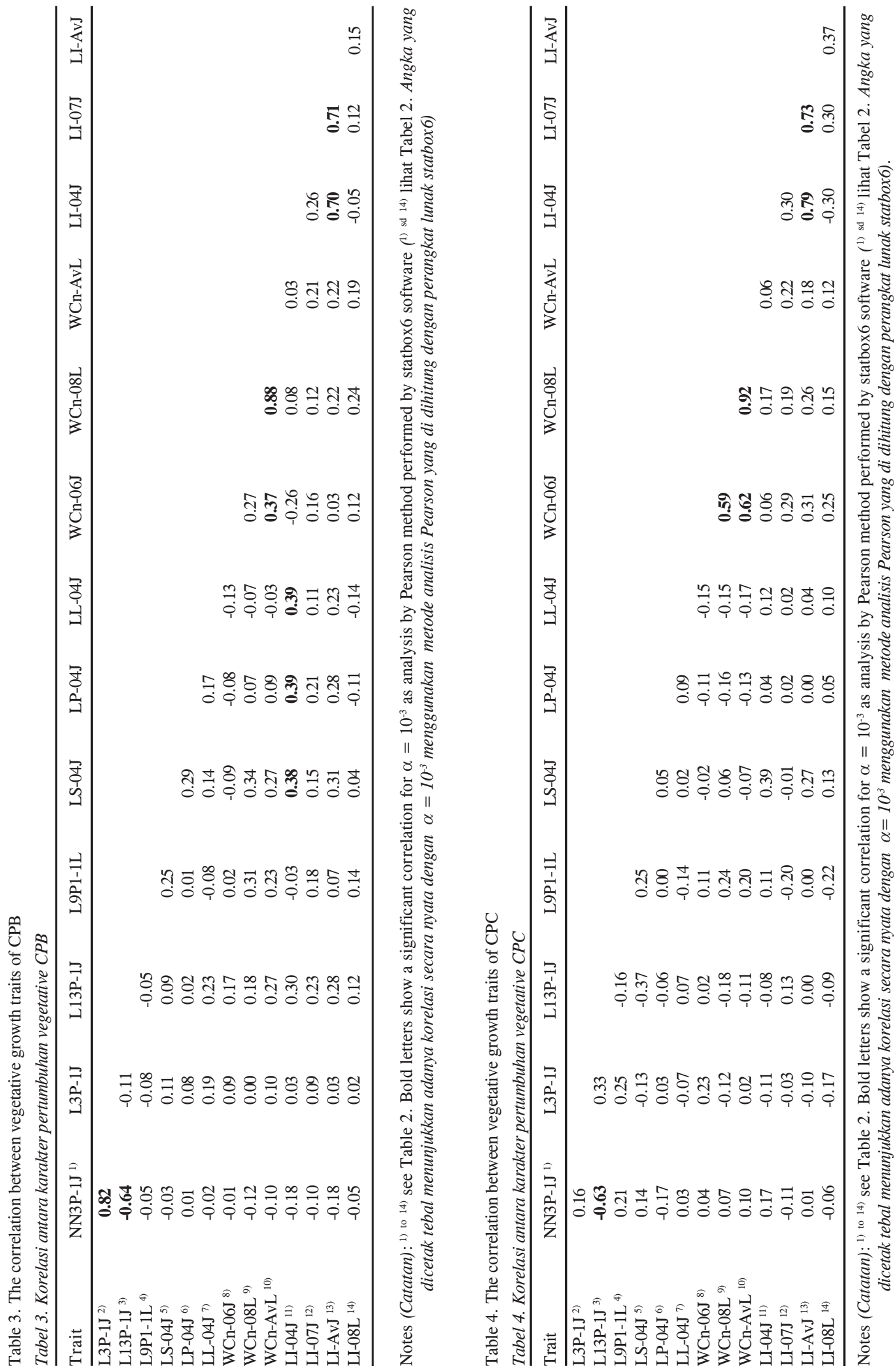

PELITA PERKEBUNAN, Volume 27, Nomor 3, Edisi Desember 2011 


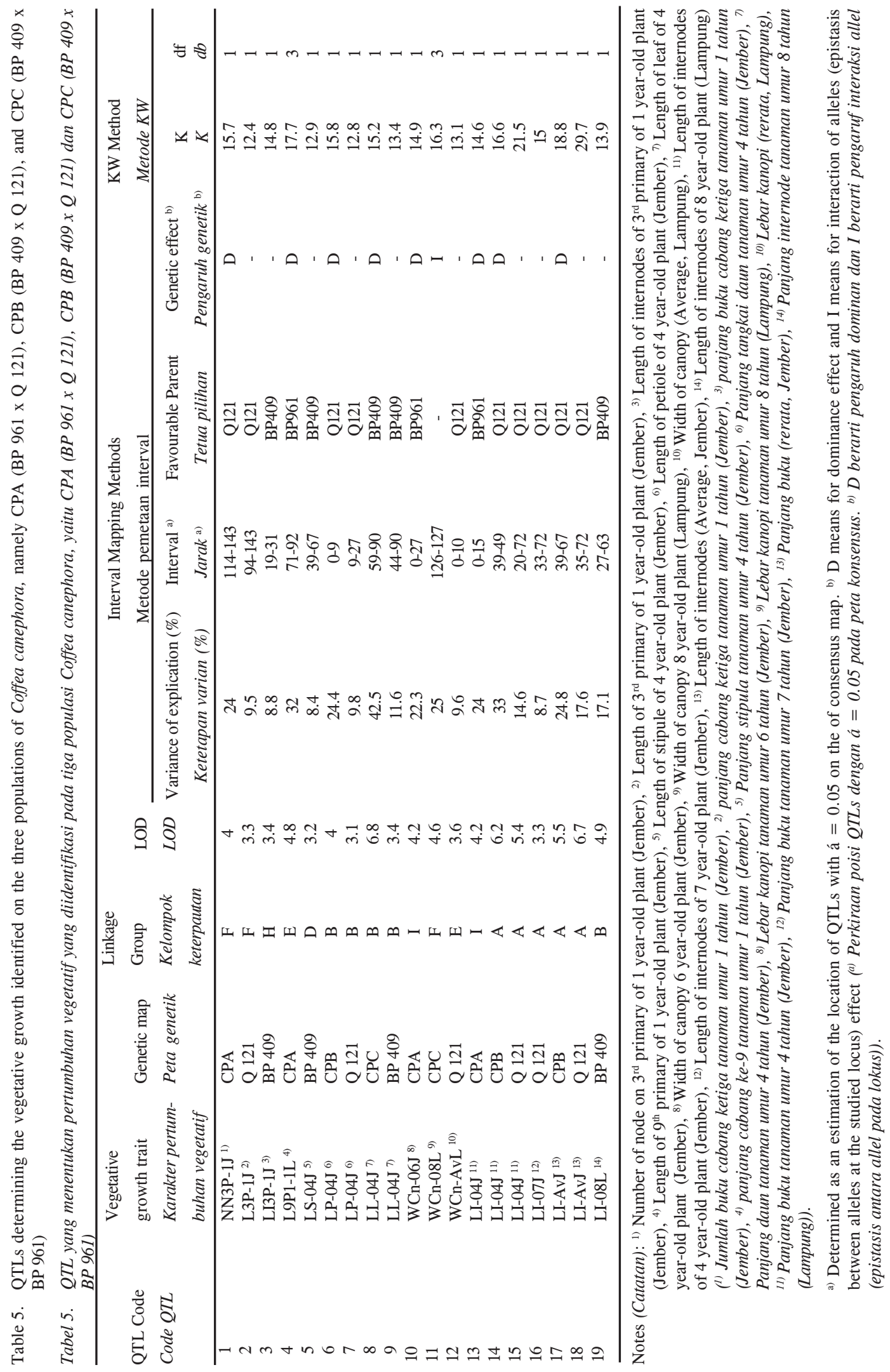

PELITA PERKEBUNAN, Volume 27, Nomor 3, Edisi Desember 2011 


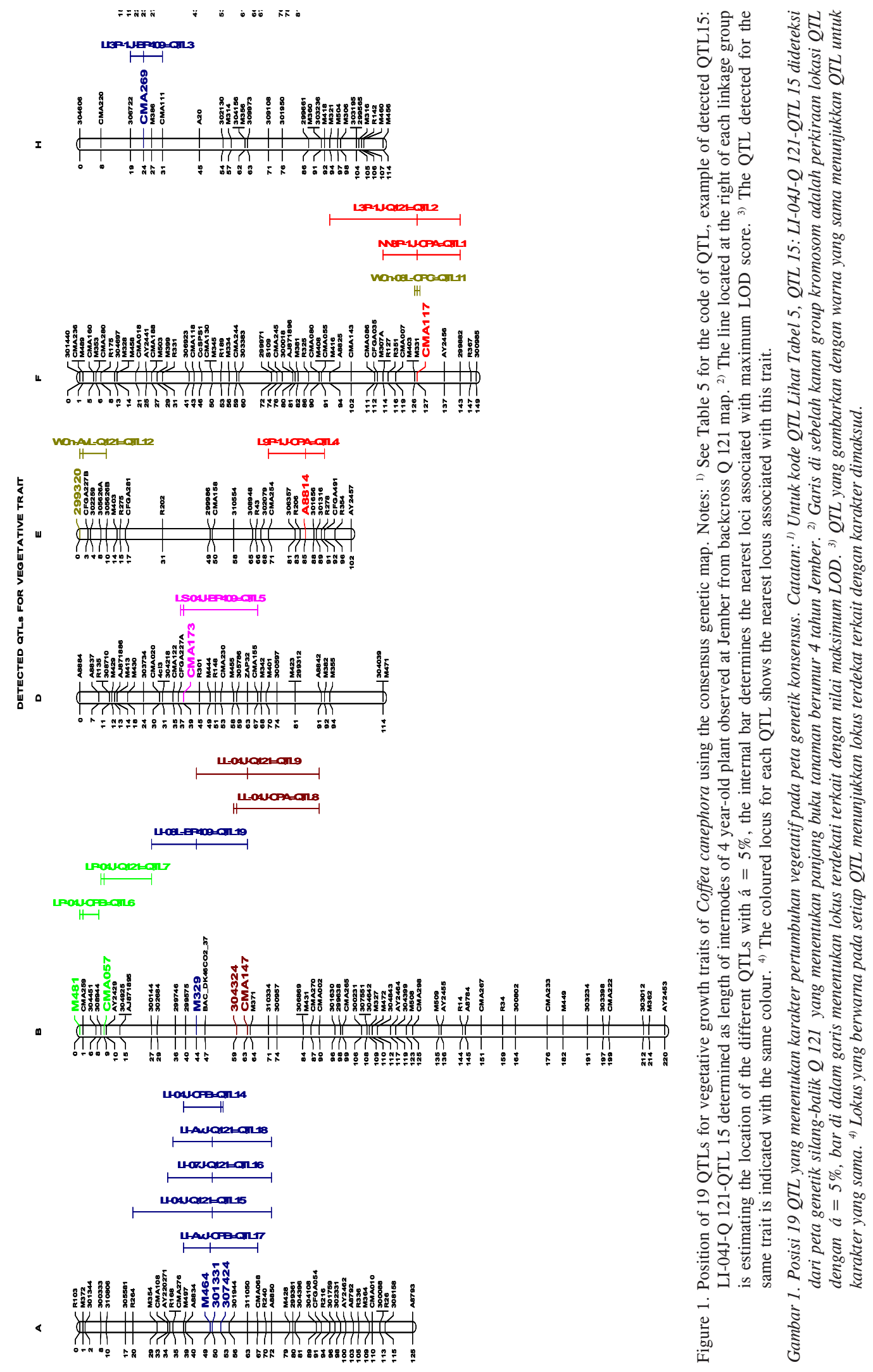

PELITA PERKEBUNAN, Volume 27, Nomor 3, Edisi Desember 2011 
netic diversity determined by molecular markers and then by yield based selection (Priyono, 1998). The three selected clones (BP 409, BP 961 and Q 121) have been shown to be quite genetically diverse. Two of them (BP 409 and BP 961) belongs to the Congolese group and are widely recommended in Indonesia. The third one (Q 121) is a natural hybrid between Guinean and Congolese (Cramer, 1957).

Concerning the phenotype characteristics of the parents, present study showed that whether it is for pre-yielding or yielding plants there is no significant difference between the three parental clones $(\alpha<0.05)$ for all vegetative traits, except for canopy width. Thus should be concluded that in this study, when considering the three parents only one of the 17 observed characteristics are significantly different.

In addition, there is no significant difference of pre-yielding vegetative characteristics between the two parents of each population. In contrast, for yielding vegetative characteristics one could note some significant differences between two parents of the populations (Table 1). However, the best parent can be either one or the other depending on the characteristic.

High variation of pre-yielding vegetative traits is observed in the three populations. Depending on the trait, the maximum differences vary from 262 to 549 \% for CPA, 219 to $1013 \%$ for CPB and 211 to $1006 \%$ for CPC. Relatively similar observation is also possible for yielding plants where the maximum differences vary from 152 to $204 \%$ for CPA, 139 to $177 \%$ for CPB and 51 to $174 \%$ for CPC depending on the trait. The distributions of all observed vegetative traits of the three populations were significantly characterized as normal ones $(\alpha<0.05)$. The high variability among descendents and the normal distribution for all traits indicate a segregation type of morphological traits similar to that of DNA markers creating good expectations for future QTL detection. The continuous of distributions let also suppose a polygenic control of these traits.

The heritability is normally estimated at $95 \%$ of confidence interval. It is another approach to estimate the genetic effect by determining the degree of inheritance of the parent's characteristics to the next generation. A previous report about $C$. canephora has shown that some traits, such as the number of nodes are heritable and other ones, such as the average length of internodes, are not (Cilas et al., 2006). Present study showed that the heritability $\left(\mathrm{h}^{2}\right)$ of pre-yielding vegetative traits, it is quite low ranging from 0.01 to 0.10 for CPA, 0.00 to 0.04 for $\mathrm{CPB}$ and 0.01 to 0.23 for CPC depending on the trait. Similar values $\left(\mathrm{h}^{2}=\right.$ from 0.00 to 0.06$)$ are observed for internodes length and canopy width of yielding plants of the three populations. In contrast, a strong heritability of stipule length, petiole length, leaf length and leaf width of yielding plants can be noticed. It ranges from 0.53 to 0.88 for CPA, 0.43 to 0.71 for $\mathrm{CPB}$, and 0.66 to 0.87 for CPC. Our result showed that, the heritability was in the low levels for most of the nine observed traits. Only two to three traits, depending on the population, had a more important heritability. Most of these traits are therefore not heritable. One may suggest that this low heritability is due to the absence of significant differences between the parents for almost all observed traits. It indicates that the direct selection for these traits could not be very successful on these populations. Using phenotypic observations, additional efforts to improve the genetic effect of these 
parental clones would therefore have quite poor benefits. The use of molecular markers and QTL approaches would help to make a breakthrough possible from these populations but also more generally for this species.

\section{QTL Analysis}

Due to multiple sites and years of observation the nine measured traits led to a total of 27 different quantitative data usable for the detection of QTLs on each of the three $C$. canephora populations.

The research of QTLs was performed on both types of genetic map developed in this study: one for cross populations $(\mathrm{CP})$ and one for backcross (BC, see Priyono et al., 2010a). It should be possible to detect QTLs on each of these different genetic maps. A LOD threshold of 4.0 for CP and 3.0 for $\mathrm{BC}$ populations has been used for interval mapping (see also Material \& Methods).

We were able to detect QTLs for vegetative traits in three $\mathrm{CPs}$ and two $\mathrm{BCs}$ (BP 409 and Q 121) populations. A total of 17 vegetative traits of pre-yielding and yielding plants were analyzed. The 19 QTLs detected for nine traits are summarized in Table 5. Among the eight traits where no QTL has been detected seven are from pre-yielding plants.

For five vegetative traits (number of node of $3^{\text {rd }}$ primary, length of $3^{\text {rd }}$ primary, length of $9^{\text {th }}$ primary, length of stipule and length of petiole) only one QTL has been detected. For the length of petiole and length of leaf, two QTLs were detected. Finally, three QTLs were detected for the width of canopy and seven for the length of internodes.

For CP maps the LOD scores of the QTLs for vegetative traits vary from 4.0 (number of node of $3^{\text {rd }}$ primary of preyielding plant) to 6.8 (length of leaf). The explained phenotypic variance ranges from $22.2 \%$ (width of canopy) to $42.3 \%$ (length of leaf).

For BC maps the LOD scores vary from 3.1 (length of petiole) to 6.7 (length of internodes) and the explained phenotypic variance from $8.4 \%$ (length of stipule) to $17.6 \%$ (length of internodes).

Deeply, four, three, and two QTLs were respectively detected from CPA, $\mathrm{CPB}$, and $\mathrm{CPC}$ populations. None of them is shared among these three populations. A total of four and six QTLs were also detected respectively from BP 409 and Q 121 BC maps.

When more than one QTL was detected (four traits) they were identified from several populations whether they are common or different (see again Table 5).

Three QTLs are detected in two populations (CPB and BCQ 121) 1) QTL determining the length of petiole, 2) QTL determining the length of internodes in 2004 at Jember, 3) QTL determining the average length over years of internodes at Jember. Another common QTL determines the leaf length in 2004 at Jember in two other populations (CPC and BP 409).

The nine vegetative traits have QTLs identified over seven different linkage groups. For example, the QTLs determining the length of stipule is detected on the linkage group D and the number of nodes of the $3^{\text {rd }}$ primary branch on linkage group $\mathrm{F}$ (Figure 1).

Finally, some QTLs determining one given trait are overlapping on the same linkage group and are coming from the same favourable parent. They are probably independent identifications of the same 
QTL. For example, QTL 14 to QTL 18 determining the internode length are overlapping on the linkage group A with Q 121 as favourable parent. Another example is for QTL 6 and QTL 7 determining the length of petiole on linkage group B.

The length of the $3^{\text {rd }}$ primary branch and the number of nodes are logically correlated $(r=0.82)$ and the corresponding QTLs overlap on linkage group F. The favourable allele comes in both cases from Q121. These two QTLs are probably a single one. Hovewer, one cannot exlude the existence of several tightly linked genes determining these two traits.

In contrary, although the QTLs for the width of the canopy, the length and number of nodes of the $3^{\text {rd }}$ primary have the same location on linkage group $\mathrm{F}$, the width of canopy is not significantly correlated (for corresponding populations) to the length and the number of nodes of the $3^{\text {rd }}$ primary. In this case one could think to different QTLs and this hypothesis is reinforced by the different genetic effect of these QTLs One is dominant and another is due to allelic interactions.

A similar conclusion can be drawn for the same traits (width of canopy and length of $3^{\text {rd }}$ primary) for QTL 10 and 13 overlapping on linkage group I.

Based on the above considerations, a total of 19 QTLs detected for vegetative traits might finally be considered as only 12 QTLs disseminated over 7 linkage groups.

Although the phenotypic values of the two parents of each population are generally not significantly different and have a low heritability, a large number of QTLs has been detected for vegetative traits. The existence of clustered favourable QTLs is possibly due to pleiotropic gene action or to tight linkage of different loci involved in these vegetative traits. However, in case of pleiotropism the QTL co-location and convergent positive effects should be expected (Crouzillat et al., 2000; Yu et al., 2007).

Coffea sp. are longlived organism facing a wide spectrum of climatic conditions during their lifetime. QTL analyses over years reveal important genotype $\mathrm{x}$ environment interactions. The influence of the environment on the reproducibility of QTL detection has been reported in species such as Eucalyptus (Verhaegen et al., 1997). Moreover, Zhuang et al. (1997) showed the QTL $\times$ environmental interaction for plant height in rice. The present study shows that repeated phenotyping over years may improve the reliability of detected QTLs but reduces the interest of this QTL based strategy due to significant increase of time for their identification. However, when having a reliable data base for interesting traits recorded in a defined population of a perennial crop for many years, one could think to run some molecular analysis taking benefits of these available data either for QTL detection or for association genetics. In some cases the missing part for running this kind of study is more on the phenotyping side than on the genotyping one.

This study also reveals that some QTLs are detected in most sites and years. The value of genotypes may well differ with the environment and the interaction between these two variables may be quite complex (Allard \& Bradshaw, 1964). Therefore, identifying QTLs consistent across environments would be desirable in a marker assisted selection (MAS) program (Paterson et al., 1991; Anderson, 2007; Collard \& Mackill, 2008).

Present paper showed that some QTLs associated with a coffee vegetative trait 
of interest were identified. However, only two of them are shared for different traits. One is shared for the width of the canopy and then number/length of primary branches and the other one for the width of the canopy and the length of internodes. These two QTLs might determine the size of the tree canopy. A similar result was reported by Fukino et al. (2008) who detected several QTLs affecting lateral branching in Cucumis melo. Moreover, several QTLs linked to vegetative trait have been reported for several plants for example bud set and bud flush in Populus (Frewen et al., 2000), for node of first fruiting branch in a cross of an upland cotton (Guo et al., 2008), soybean plant height (Lee et al., 1996), morphological traits of Brassica rapa (Lou et al., 2007), and plant height in rice (Zhuang et al., 1997). Interestingly, TimmermanVaughan et al. (2005) describing QTLs for pea development are overlapping with yield QTLs. Other results also showed the high relationship between QTLs for vegetative trait and yield, namely flag leaf characteristics yield and yield traits in rice (Yue et al., 2006). In coffee, the canopy width plays an important role for planting density which contributes directly to the productivity. Today, the quality of canopy is evaluated by slimness but also by compactness of the branching system. Breeding C. canephora for an ideal canopy has been difficult because it is greatly affected by the genetic and environmental factors. DNA markers discovered in this study might facilitate an effective breeding for branching in this crop.

A few examples the using of QTL for vegetative trait for MAS has been reported such as for multiple lateral branching in cucumber (Cucumis sativus L.) (Fazio et al., 2003). Promisingly, at least some of the markers discovered in this study will be useful for MAS for key coffee ve- getative growth traits. The next step should be the determination of a selection index in order to select the most important QTLs to be managed during further breeding work.

\section{CONCLUSION}

1. Based on phenotypic observations, most of vegetative growth traits observed are therefore not heritable. It could be suggested that using phenotypic observations, additional efforts to improve the genetic effect of these parental clones would therefore have quite poor benefits. It indicates that the direct selection for these traits could not be very successful on these populations.

2. Thank to the high variability among descendents and the normal distribution for all traits indicate a segregation type of morphological traits are similar to that of DNA markers in this study resulting of 12 QTLs determining of 9 vegetative growth traits can be detected.

\section{ACKNOWLEDGEMENT}

The authors thank to Indonesian Coffee and Cocoa Research Institute, PT Nestle Indonesia, and Nestle R\&D Centre Tours for supporting this project.

\section{REFERENCES}

Akaffou, D.S.; C.L. Ky; P. Barre; S. Hamon; J. Louarn \& M. Noirot (2003). Identification and mapping of a major gene (F1t) involved in fructification time in interspecific cross coffea psedo-zanguebariae x $C$. liberica var Dewevrei: impact on caffeine content and seed weight. Theoretical Applied Genetics, 108, 14861490. 
Allard, R.W. \& A.D. Bradshaw (1964). Implication of environment interaction in applied plant breeding. Crop Science, 4, 503-508.

Anderson, J.A. (2007). Marker-assisted selection for Fusarium head blightresistance in wheat. International Journal of Food Microbiology, 119, 51-53.

Bouharmont, P. ; R. Lotodé; J. Awemo \& X. Castaing (1986). La sélection générative du caféier robusta au Cameroun. Analyse des resultats d'un essai d'hybrides diallèle partie implante en 1973. Café Cacao Thé, 30, 93-112.

Cilas, C.; A. Bar-Hen; C. Montagnon \& C. Godin (2006). Definition of architectural ideotypes for good yield capacity in Coffea canephora. Annual of Botany, 97, 405-411.

Collard, B.C.Y. \& D.J. Mackill (2008). Marker-assisted selection: an approach for precision plant breeding in the twenty-first century. Phil Trans Res Soc., 263, 557-572.

Coulibaly, I.; J. Louarn; M. Lorieux; A. Charrier; S. Hamon \& M. Noirot (2003). Pollen viability restoration in Coffea canephora Pierre and $C$. heterocalyx Stoffelen backcross. QTL identification for marker-assisted selection. Theoretical Applied Genetics, 106, 311-316.

Cramer, P.J.S. (1957). Review of Coffee Research in Indonesia. Inter-American Institute of Agricultural Science, Turrialba, Costa Rica. 262p.

Crouzillat, D.; B. M'enard; A. Mora; W. Phillips \& V. Pétiard (2000). Quantitative trait analysis in Theobroma cacao using molecular markers; Yield QTL detection and stability over 15 years. Euphytica, 114, 13-23.

Eskes, A.B. \& T. Leroy (2004). Coffee selection and breeding. p. 58-86. In: J.N. Wintgens (ed). Coffee: Growing, Processing, Sustainable Produc- tion, A Guidebook for Growers, Processors, Traders, and Researchers. Wiley-VCH; Weinhelm; Wiley; pp. 58-86.

Fan, Z.; M.D. Robin \& J.E. Staub (2006). Population development by phenotypic selection with subsequent markerassisted selection for line extraction in cucumber (Cucumis sativus L.). Theoritical Applied Genetic, 112, 843855.

Fazio, G.; S.M. Chung \& J.E. Staub (2003). Comparative analysis of response to phenotypic and marker-assisted selection for multiple lateral branching in cucumber (Cucumis sativus L.). Theoretical Applied Genetetic, 107, 875-883.

Frewen, B.F.; T. Chen; G.T. Howe; J. Davis; A. Rohde; W. Boerjan \& H.D. Bradshaw (2000). Quantitative trait loci and candidate gene mapping of bud set and bud flush in Populus. Genetic, 154, 837-845.

Fukino, N.; M. Sugiyama; T. Ohara; H. Sainoki; N. Kubo; M. Hirai; S. Matsumoto \& Y. Sakata (2008). Detection of quantitative trait loci affecting short lateral branching in Cucumis melo. Proceedings of the $I X^{\text {th }}$ EUCARPIA meeting on genetics and breeding of Cucurbitaceae, INRA, Avignon (France), May 21-24 $4^{\text {th }}, 2008$.

Guo, Y.; J.C. McCarty; J.N. Jenkins; S. Saha (2008). QTLs for node of first fruiting branch in a cross of an upland cotton, Gossypium hirsutum L., cultivar with primitive accession Texas 701 . Euphytica, 163, 113-122.

Hendre, P.S. \& R.K. Aggarwal (2007). DNA markers: development and application for genetic improvement of coffee. p. 399-434. In: R.K. Varshney; R. Tuberrosa (eds) Genomic Assisted crop Improvement Vol 2: genomic Application in Crops, Springer.

Iswanto, A.; S. Abdoellah \& S. Mawardi (1984). Kajian tentang pemberian air 
dalam mengatasi rintangan penyilangan pada tanaman kopi. Menara Perkebunan, 52, 204-212.

Ky, C.L.; B. Guyot; J. Louarn; S. Hamon \& M. Noirot (2001a). Trigonelline inheritance in the interspecific Coffea pseudozanguebariae $x$ C. liberica var. dewevrei cross. Theoretical Applied Genetics, 102, 630-634.

Ky, C.L.; J. Louarn; S. Dussert; B. Guyot; S. Hamon \& M. Nairot (2001b). Caffeine, Trigonelline, Chlorogenic acids and sucro diversity in wild Coffea arabica and $C$. canephora accession. Food Chemistry, 75, 223-230.

Lee, S.H.; M.A. Bailey; M.A. Mian; T.E. Carter; D.A. Ashley; R.S. Hussy; W.A. Parrott \& H.R. Boerma (1996). Molecular markers associated with soybean plant height; loging; and maturity across locations. Crop Science, 36, 728-735.

Lefebvre-Pautigny, F.; F. Wu; M. Philippot; M. Rigoreau; Priyono; M. Zouine; P. Frasse; M. Bouzayen; P. Broun; V. Pétiard; S.D. Tanksley \& D. Crouzillat (2010). High resolution synteny maps allowing direct comparisons between the coffee and tomato genomes. Tree Genetics and Genomes, 6, 565-577.

Leroy, T.; C. Montagnon; C. Cilas; A. Charrier (1994). Reciprocal recurrent selection applied to Coffea canephora Pierre. II. Estimation of genetic parameters. Euphytica, 74, 121-128.

Lou, P.; J. Zhao; J.S. Kim; S. Shen; D.P. Del Carpio; X. Song; I. Jin ; D. Vreugdenhil; X. Wang; M. Koorneef \& G. Bonnema (2007). Quantitative trait loci for flowering time and morphological traits in multiple population of Brassica rapa. Journal Experimental Botany, 58, 4005-4016.

Paterson, A.H.; S. Damon; J. Hewitt; D. Zamir; H.D. Rabinowitch; S.E. Lincoln et al. (1991). Mendelian factors underlying quantitative traits in tomato: comparison across species, generations and environments. Genetics, 127, 181-197.

Poncet, V.; M. Dufour; P. Hamon; S. Hamon; A. de Kochko \& T. Leroy (2007). Development of genomic microsatellite markers in Coffea canephora and their transferability to other coffee species. Genome, 50, 1156-1161.

Priyono (1998). Cartographie Genetique d'une Population F1 de Coffea canephora. Memoire de DIRS, Universite de Tours, France.

Priyono; M. Rigoreau \& D. Crouzillat (2010a). Evaluation of transferability of simple sequence repeats (SSR) and single nucleotide polymorphisms (SNP) marker for genetic map development in Robusta coffee (Coffea canephora Pierre). Pelita Perkebunan, 26, 126-141.

Priyono; B. Florin; M. Rigoreau; J.P. Ducos; U. Sumirat; S. Mawardi; C. Lambot; P. Broun; V. Pétiard; W. Wahyudi \& D. Crouzillat (2010b). Somatic embryogenesis and vegetative cutting capacity are under distinct genetic control in Coffea canephora Pierre. Plant Cell Rep., 29, 343-357.

Schmidt, F.H. \& J.H.A. Ferguson (1951). Rainfall types based on wet and dry period ratios for Indonesia with Western New Guinea. Verhandelingen no. 4, Kementerian Perhubungan Djawatan Meteorologi dan Geofisika, Jakarta.

Timmerman-Vaughan, G.M.; A. Mills; C. Whitfield; T. Frew; R. Butler; S. Murray; M. Lakeman; J. McCallum; A. Russell \& D. Wilson (2005). Linkage mapping of QTL for seed yield, yield components, and developmental traits in pea. Crop Science, 45, $1336-1344$

Van Ooijen, J.W. (2004). Map QTL ${ }^{\text {ò }} 5$ software for the mapping of quantitative trait loci in experimental populations. Kyazma, Wageningen. 
Van Ooijen, J.W. (2006). Joinmapò 4 software for the calculation of genetic linkage maps in experimental populations. Kyazma, Wageningen.

Verhaegen, D.; C. Plomion; G.M. Gion; M. Poitel; P. Costa \& A. Kremer (1997). Quantitative trait dissection analysis in Eucalyptus using RAPD markers: 1. Detection of QTL in interspecific hybrid progeny, stability of QTL expression across different ages. Theoretical Applied Genetics, 95, 597-608.

Yu, J.K.; E. Graznak; F. Breseghello; H. Tefera \& M.E. Sorrells (2007). QTL mapping of agronomic traits in tef (Eragrostis tef (Zucc) Trotter). BMC Plant Biology, 7, 30.
Yue, B.; W.Y. Xue; L.J. Luo \& Y.Z. Xing (2006). QTL analysis for flag leaf characteristics and their relationships with yield and yield traits in rice. Yi Chuan Xие Bao, 33, 824-832.

Zhuang, J.Y.; H.X. Lin; J. Lu; H.R. Qian; S. Hittalmani; N. Huang \& K.L. Zheng (1997). Analysis of QTL $\times$ environmental interaction for yield components and plant height in rice. Theoretical Applied Genetics, 95, $799-808$

PELITA PERKEBUNAN, Volume 27, Nomor 3, Edisi Desember 2011 